\title{
Survei Tingkat Kondisi Fisik Peserta Ekstrakurikuler Futsal Putri SMA Negeri 2 Batu
}

\author{
Wildan Wimba Bastian*, Eko Hariyanto \\ Universitas Negeri Malang, Jl. Semarang No. 5 Malang, Jawa Timur, Indonesia \\ *Penulis korespondensi, Surel: wildanwimba@gmail.com
}

Paper received: 24-5-2021; revised: 14-6-2021; accepted: 21-6-2021

\begin{abstract}
Abstrak
Olahraga futsal bukan hanya teknik dan taktik saja yang diperlukan, melainkan juga kondisi fisik yang baik. Demikian juga pada kegiatan ekstrakurikuler futsal putri SMA Negeri 2 Batu, kondisi fisik yang buruk akan berdampak terhadap penampilan teknik dan taktik peserta. Tujuan penelitian ini adalah untuk mengetahui tingkat kondisi fisik peserta ekstrakurikuler futsal putri SMA Negeri 2 Batu. Penelitian ini termasuk penelitian deskriptif menggunakan metode survei dengan pengumpulan data menggunakan tes dan pengukuran. Hasil keseluruhan kondisi fisik peserta ekstrakurikuler futsal putri SMA Negeri 2 Batu yaitu terdapat dua unsur yang menunjukkan kategori "Rata-rata" yaitu kelincahan dan kelentukan, sedangkan unsur daya tahan, kecepatan dan daya ledak menunjukkan kategori "Di bawah rata-rata" dan "kurang". Dari lima unsur kondisi fisik dapat disimpulkan bahwa kondisi fisik menunjukkan kategori "Cukup".
\end{abstract}

Kata kunci: kondisi fisik; futsal; ekstrakurikuler

\section{Pendahuluan}

Olahraga merupakan aktivitas yang banyak digemari oleh masyarakat luas, karena olahraga memiliki banyak manfaat untuk fisik seseorang. Latihan olahraga aerobik bermanfaat untuk meningkatkan kebugaran fisik (Palar, Wongkar, \& Ticoalu, 2015). Seiring perkembangan zaman, olahraga di Indonesia berkembang dengan cepat. Banyaknya cabang olahraga baru yang berkembang di lingkungan masyarakat Indonesia adalah menjadi salah satu bukti. Cabang olahraga baru yang berkembang di Indonesia adalah futsal. Futsal terdiri dari kata futbol sala dalam bahasa Spanyol berarti sepakbola dimainkan di dalam ruangan (Lhaksana, 2011). Futsal adalah aktivitas permainan invasi (invasion games) yang dimainkan oleh lima orang dalam satu tim dengan durasi waktu tertentu dan dimainkan di lapangan yang memiliki gawang serta menggunakan bola yang memiliki ukuran lebih kecil daripada sepakbola dan mengandalkan kecepatan bergerak seseorang pemain dimana tim pemenang adalah yang lebih banyak mencetak gol. Olahraga futsal mulai merambah ke Indonesia pada tahun 2002. Olahraga futsal mulai masuk dalam lingkungan sekolah, kampus, sampai perusahaan. Dari waktu ke waktu permainan ini mulai digemari oleh masyarakat khususnya pelajar dan Mahasiswa karena permainannya yang sederhana dan menyenangkan.

Seiring perkembangan zaman, futsal mulai memasuki dunia pendidikan. Sehingga banyak sekolah di Indonesia yang mengadakan ekstrakurikuler futsal sebagai sarana dalam menyalurkan bakat dan minat peserta didik dalam bermain futsal. Ekstrakurikuler merupakan kegiatan yang dilakukan di luar jam pembelajaran sekolah berdasarkan bakat dan minat. Sehingga bakat dan minat siswa dapat terus dikembangkan untuk meningkatkan prestasi nonakademik. Kegiatan ekstrakurikuler sangat berpengaruh positif yaitu memberikan motivasi terhadap prestasi belajar. Selain mengembangkan bakat dan minat, kegiatan ekstrakurikuler di sekolah diharapkan kemampuan kognitif, afektif dan psikomotor mengalami peningkatan. 
Dalam kegiatan ekstrakurikuler tidak hanya mengutamakan aspek psikomotor saja, melainkan juga menanamkan aspek kognitif dan aspek afektif seperti sikap sosial, tanggung jawab dan disiplin pada saat proses kegiatan ekstrakurikuler berlangsung. Sehingga dengan diadakannya kegiatan ekstrakurikuler diharapkan akan terjadi keseimbangan antara kemampuan akademik dan nonakademik

SMA Negeri 2 Batu adalah salah satu sekolah yang sudah mengadakan dan mengembangkan kegiatan ekstrakurikuler. Terdapat berbagai macam ekstrakurikuler yang diadakan di SMA Negeri 2 Batu salah satunya adalah ekstrakurikuler futsal. Banyak juga wanita yang meminati olahraga futsal, hal ini dibuktikan dengan diadakannya ekstrakurikuler futsal putri di SMA Negeri 2 Batu. Ekstrakurikuler tidak hanya bertujuan untuk menyalurkan minat dan bakat peserta didik, melainkan bisa digunakan sebagai sarana untuk mengasah kemampuan untuk mencapai prestasi dalam bidang tertentu contohnya futsal. Pencapaian prestasi futsal tentunya dibutuhkan teknik dasar serta taktik yang baik. Dalam olahraga futsal bukan hanya teknik dan taktik saja yang diperlukan, melainkan juga kondisi fisik yang prima. Kondisi fisik yang buruk maka berdampak buruk juga pada penampilan teknik dan taktik seorang pemain (Lhaksana, 2011). Sehingga dalam olahraga futsal pemain harus memiliki teknik dasar yang baik, strategi yang baik dan juga tidak kalah penting adalah kondisi fisik yang prima.

Dalam olahraga futsal, pelatih dituntut untuk mengoptimalkan komponen fisik para pemain. Komponen fisik hampir sama dengan komponen kebugaran jasmani, komponen kebugaran jasmani meliputi kecepatan, keseimbangan, kelincahan, koordinasi, daya tahan, kelentukan, kekuatan, daya ledak, waktu reaksi dan komposisi tubuh (Wiarto, 2013). Berdasarkan komponen-komponen fisik di atas, komponen yang paling dominan pada futsal adalah unsur daya tahan, kecepatan, kelincahan, daya ledak, kelentukan dan tentu juga didukung dengan komponen fisik yang lainnya. Tidak hanya faktor teknik, strategi dan kondisi fisik, faktor latihan juga berpengaruh terhadap pencapaian prestasi atlet. Frekuensi latihan harus diperhatikan oleh seorang pelatih, untuk kategori olahraga prestasi latihan dilaksanakan minimal 3 kali dalam 1 minggu. Pada olahraga prestasi frekuensi latihannya sebanyak 3-6 kali dalam 1 minggu, sedangkan pada olahraga kebugaran atau kesehatan frekuensi yang dilakukan adalah 1-3 kali dalam 1 minggu (Rahayu, 2017).

Berdasarkan observasi yang telah dilakukan pada awal bulan Oktober 2019, kegiatan ekstrakurikuler futsal putri di SMA Negeri 2 Batu dilaksanakan 1 minggu sekali pada hari selasa. Ekstrakurikuler futsal putri mulai terbentuk pada tahun 2018. Dalam kegiatan ekstrakurikuler tersebut seringkali hanya fokus pada latihan teknik dan taktik saja, pelatih tidak banyak melakukan latihan fisik, pelatih juga belum pernah melakukan tes kondisi fisik peserta ekstrakurikuler futsal putri. Seharusnya seorang pelatih memiliki data kondisi fisik pemainnya guna menentukan latihan yang ingin diterapkan pada saat kegiatan ekstrakurikuler berlangsung. Faktor lain yang harus diperhatikan adalah frekuensi latihan, karena dalam olahraga prestasi dibutuhkan frekuensi latihan minimal 3 kali dalam 1 minggu sedangkan pada ekstrakurikuler futsal putri SMA Negeri 2 Batu hanya dilakukan 1 kali dalam 1 minggu, oleh karena itu perlu diadakan latihan tambahan untuk mengasah kemampuan khususnya pada kondisi fisik pemain guna mencapai prestasi yang maksimal. Mengingat pentingnya kondisi fisik dalam olahraga futsal, maka dari itu peneliti tertarik untuk mengetahui bagaimana kondisi fisik peserta ekstrakurikuler futsal putri di SMA Negeri 2 Batu, maka peneliti tertarik untuk 
melakukan penelitian yang berjudul "Survei Tingkat Kondisi Fisik Peserta Ekstrakurikuler Futsal Putri SMA Negeri 2 Batu".

\section{Metode}

Rancangan dalam penelitian ini adalah rancangan survei. Teknik pengumpulan data yang digunakan adalah tes dan pengukuran karena data yang diperoleh dalam bentuk angka. Penelitian ini menggunakan analisis deskriptif kuantitatif dengan rumus persentase.

Subjek dalam penelitian ini berjumlah 30 peserta ekstrakurikuler futsal putri SMA Negeri 2 Batu. Teknik pengambilan data menggunakan total sampling, yaitu mengambil populasi secara keseluruhan. Subjek penelitian berjumlah 30 peserta ekstrakurikuler futsal putri SMA Negeri 2 Batu.

Instrumen tes menggunakan multistage fitness test untuk mengukur daya tahan kardiovaskular, illinois agility run test untuk mengukur kelincahan, tes lari 30 meter untuk mengukur kecepatan, vertical jump test untuk mengukur daya ledak otot tungkai, dan sit and reach test untuk mengukur kelentukan.

Setelah data tes dan pengukuran terkumpul langkah selanjutnya menilai tingkat kondisi fisik dengan melihat pada tabel nilai dan tabel norma yang berguna untuk menentukan kategori tingkat kondisi fisik. Setiap data yang diperoleh dari tiap item tes merupakan data kasar yang selanjutnya diubah menjadi nilai Skor-T dengan rumus T-Skor. Langkah selanjutnya adalah melakukan analisis data guna menarik kesimpulan dari penelitian yang sudah dilakukan. Analisis data yang digunakan adalah teknik analisis deskriptif kuantitatif dengan persentase.

\section{Hasil dan Pembahasan}

\subsection{Hasil}

Berdasarkan hasil analisis data deskriptif kuantitatif terhadap subyek penelitian setelah diperoleh data kasar dari pelaksanaan hasil tes, kemudian mengkonversikan data kasar menjadi skor-T dari masing-masing tes selanjutnya menganalisis data guna menentukan kategori tingkat kondisi fisik peserta. Hasil dari tiap tes dapat dikategorikan sebagai berikut.

\subsubsection{Komponen Daya Tahan Kardiovaskular Multistage Fintess Test}

Tabel 1. Kategori Kondisi FisikKomponen Daya Tahan Kardiovaskular Multistage Fintess Test

\begin{tabular}{clcc}
\hline $\begin{array}{c}\text { Interval } \\
\text { (ml/kg/min) }\end{array}$ & \multicolumn{1}{c}{ Kategori } & Frekuensi & Presentase (\%) \\
\hline$>41,9$ & Superior (Unggul) & 0 & 0 \\
$39,0-41,9$ & Excellent (Sangat Baik) & 1 & 3,33 \\
$35,0-38,9$ & Good (Baik) & 1 & 3,33 \\
$31,0-34,9$ & Fair (Sedang) & 5 & 16,67 \\
$25,0-30,9$ & Poor (Kurang) & 15 & 50 \\
$<25,0$ & Very (Poor Sangat Kurang) & 8 & 26,67 \\
\hline & Jumlah & 30 & 100 \\
\hline
\end{tabular}




\subsubsection{Komponen Kelincahan Illinois Agility Run Test}

Tabel 2. Kategori Kondisi Fisik Komponen Kelincahan Illinois Agility Run Test

\begin{tabular}{clcc}
\hline $\begin{array}{c}\text { Interval } \\
\text { (detik) }\end{array}$ & \multicolumn{1}{c}{ Kategori } & Frekuensi & Presentase (\%) \\
\hline$<17,0$ & Excellent (Baik sekali) & 0 & 0,00 \\
$17,0-17,9$ & Above Average (Di atas rata-rata) & 0 & 0,00 \\
$18,0-21,7$ & Average (Rata-rata) & 14 & 46,67 \\
$21,8-23,0$ & $\begin{array}{l}\text { Below Average (Di bawah rata- } \\
\text { rata) }\end{array}$ & 9 & 30,00 \\
& Poor (Kurang) & 7 & 23,33 \\
\hline 23,0 & Jumlah & 30 & 100 \\
\hline
\end{tabular}

\subsubsection{Komponen Kecepatan Tes Lari 30 Meter}

Tabel 3. Kategori Kondisi Fisik Komponen Kecepatan Tes Lari 30 Meter

\begin{tabular}{clcc}
\hline $\begin{array}{c}\text { Interval } \\
\text { (detik) }\end{array}$ & \multicolumn{1}{c}{ Kategori } & Frekuensi & Presentase (\%) \\
\hline$<4,5$ & Excellent (Baik sekali) & 0 & 0,00 \\
$4,6-4,5$ & Above Average (Di atas rata-rata) & 0 & 0,00 \\
$4,8-4,7$ & Average (Rata-rata) & 2 & 6,67 \\
$5,0-4,9$ & Bellow Average (Di bawah rata- & 1 & 3,33 \\
& rata) & 27 & 90,00 \\
$>5,0$ & Poor (Kurang) & 30 & 100 \\
\hline
\end{tabular}

\subsubsection{Komponen Daya Ledak Otot Tungkai Vertical Jump Test}

Tabel 4. Kategori Kondisi Fisik Komponen Daya Ledak Otot Tungkai Vertical Jump Test

\begin{tabular}{clcc}
\hline Interval (cm) & Kategori & Frekuensi & Presentase (\%) \\
\hline$>58$ & Excellent (Baik sekali) & 0 & 0,00 \\
$47-58$ & Above Average (Di atas rata-rata) & 0 & 0,00 \\
$36-46$ & Average (Rata-rata) & 7 & 23,33 \\
$26-35$ & Bellow Average (Di bawah rata- & 15 & 50,00 \\
& rata) & 8 & 26,67 \\
\hline$<26$ & Poor (Kurang) & 30 & 100 \\
\hline
\end{tabular}

\subsubsection{Komponen Kelentukan Sit and Reach Test}

Tabel 5. Kategori Kondisi Fisik Komponen Kelentukan Sit and Reach Test

\begin{tabular}{clcc}
\hline Interval (cm) & Kategori & Frekuensi & Presentase (\%) \\
\hline$>15$ & Excellent (Baik sekali) & 3 & 10,00 \\
$12-15$ & Above Average (Di atas rata-rata) & 3 & 10,00 \\
$7-11$ & Average (Rata-rata) & 11 & 36,67 \\
$4-6$ & Bellow Average (Di bawah rata- & 10 & 33,33 \\
& rata)
\end{tabular}




\begin{tabular}{clcc}
\hline Interval (cm) & Kategori & Frekuensi & Presentase (\%) \\
\hline$<4$ & Poor (Kurang) & 3 & 10,00 \\
\hline & Jumlah & 30 & 100 \\
\hline
\end{tabular}

Dari lima unsur kondisi fisik yang sudah diteliti terdapat 2 unsur yang berada pada kategori rata-rata yaitu kelincahan dan kelentukan, sedangkan unsur daya tahan, kecepatan dan daya ledak berada pada kategori di bawah rata-rata dan kurang. Sedangkan secara keseluruhan kondisi fisik peserta ekstrakurikuler futsal putri SMA Negeri 2 Batu dapat dilihat pada tabel sebagai berikut.

\subsubsection{Kondisi Fisik Secara Keseluruhan}

Tabel 5. Kategori Kondisi Fisik Secara Keseluruhan

\begin{tabular}{llcc}
\hline \multicolumn{1}{c}{ Interval (cm) } & \multicolumn{1}{c}{ Kategori } & Frekuensi & Presentase (\%) \\
\hline $\mathrm{X} \geq 276,94$ & Sangat Baik & 4 & 13 \\
$258,98 \leq \mathrm{X}<276,94$ & Baik & 6 & 20 \\
$241,02 \leq \mathrm{X}<258,98$ & Cukup & 10 & 33 \\
$223,06 \leq \mathrm{X}<241,02$ & Kurang & 9 & 30 \\
$\mathrm{X} \leq 223,06$ & Sangat Kurang & 1 & 3 \\
\hline & Jumlah & 30 & 100 \\
\hline
\end{tabular}

\subsection{Pembahasan}

Berdasarkan hasil analisis data dari lima komponen tes kondisi fisik peserta ekstrakurikuler futsal putri SMA Negeri 2 Batu unsur daya tahan kardiovaskular paling banyak menunjukkan kategori "Kurang" dengan persentase 50\%. Rendahnya tingkat daya tahan kardiovaskular dikarenakan kurangnya latihan fisik dan belum adanya program latihan yang tersusun. Unsur kondisi fisik sangat berpengaruh terhadap permainan futsal, karakteristik permainan futsal yang cepat mengharuskan pemain selalu bergerak, sehingga membutuhkan daya tahan kardiovaskular yang tinggi. Oleh karena itu terdapat pengaruh antara permainan futsal dan daya tahan kardiovaskular (Sumantri, Supriatna, \& Syukri, 2013).Dalam meningkatkan daya tahan kardiovaskular diperlukan latihan seperti circuit training, karena latihan circuit training berpengaruh terhadap peningkatan daya tahan aerobic seseorang (Satria, 2019).

Unsur kelincahan menunjukkan kategori "Rata-rata" dengan persentase 46,67\%. Kelincahan memiliki hubungan yang sangat kuat terhadap kemampuan dribbling futsal (Gunawan, Suherman, \& Sudirjo, 2016). Dalam permainan futsal, kelincahan berpengaruh besar pada futsal, khususnya pada saat pemain melakukan dribbling. Peserta ekstrakurikuler futsal putri SMA Negeri 2 Batu perlu meningkatkan unsur kelincahan dengan latihan Ladder drills. Latihan Ladder drills adalah latihan dengan tangga latihan guna melatih kelincahan gerak. Latihan Ladder drills berpengaruh lebih baik dibandingkan dengan latihan konvensional terhadap peningkatan kelincahan gerak (Hadi, Haryanto, \& Fahrial Amiq, 2016).

Unsur kecepatan menunjukkan kategori "Kurang" dengan persentase 90,00\%. Kecepatan sangat berpengaruh pada permainan futsal. Karakteristik permainan futsal yang cepat membuat pemain harus mempunyai kecepatan yang baik khususnya pada saat melakukan dribble bola. Untuk meningkatkan kecepatan peserta dilakukan latihan kecepatan 
seperti lompat kijang. latihan lompat kijang dengan irama cepat dan irama lambat dapat meningkatkan kecepatan lari, sedangkan latihan lompat kijang irama cepat berpengaruh lebih baik dari pada latihan lompat kijang irama lambat dalam meningkatkan kecepatan lari (Johan Cahyo B, Musyafari Waluyo, 2012)

Unsur daya ledak otot tungkai menunjukkan kategori "Di bawah rata-rata" dengan persentase 50,00\%. Daya ledak otot tungkai sangat penting dalam futsal, khususnya pada saat melakukan shooting. Daya ledak otot tungkai memiliki hubungan yang signifikan dengan hasil kemampuan shooting futsal (Putra, 2014). Daya ledak otot tungkai dapat ditingkatkan dengan latihan yang menunjang daya ledak seseorang contohnya latihan squat. Contoh latihan squat adalah latihan quarter squat yang dapat meningkatkan daya ledak otot tungkai dengan baik daripada melakukan latihan half squat.no

Unsur kelentukan menunjukkan kategori "Rata-rata" dengan persentase 36,67\%. Kelentukan sangat berpengaruh pada permainan futsal, khususnya pada saat melakukan dribbling bola karena ada pengaruh yang signifikan kelentukan dengan menggiring bola dengan persentase 38\% (Purnomo, 2018).

Dari lima unsur kondisi fisik yang sudah diteliti terdapat 2 unsur yang berada pada kategori rata-rata yaitu kelincahan dan kelentukan, sedangkan unsur daya tahan, kecepatan dan daya ledak berada pada kategori di bawah rata-rata dan kurang. Melihat hasil penelitian tersebut dapat dikatakan bahwa tingkat kondisi fisik peserta ekstrakurikuler futsal putri SMA Negeri 2 Batu masih rendah. Dalam hal ini peneliti menyimpulkan beberapa penyebab rendahnya tingkat kondisi fisik peserta ekstrakurikuler futsal putri SMA Negeri 2 Batu diantaranya sebagai berikut:

\subsubsection{Frekuensi Latihan}

Kegiatan ekstrakurikuler futsal hanya dilakukan satu kali dalam seminggu, seharusnya frekuensi latihan yang baik untuk mendukung kondisi fisik dan prestasi seseorang harus dilakukan minimal 1-3 kali dalam satu minggu, karena dalam olahraga prestasi frekuensi latihan dilakukan sebanyak 3-6 kali dalam 1 minggu, sedangkan olahraga kebugaran atau kesehatan frekuensi latihan yang dilakukan sebanyak 1-3 kali dalam 1 minggu". Peningkatan intensitas latihan akan berpengaruh terhadap $\mathrm{VO}_{2}$ Maks (Dewangga, 2014).

\subsubsection{Latihan Fisik}

Faktor kondisi fisik sangat berpengaruh terhadap keterampilan seorang pemain futsal. Seseorang yang memiliki kondisi fisik yang baik maka keterampilan bermain futsal juga akan baik.. Hasil dari observasi yang sudah dilakukan, latihan cenderung pada teknik dan taktik saja, pelatih tidak banyak melakukan latihan fisik. Padahal unsur fisik sangat diperlukan pemain guna menampilkan permainan yang maksimal. Peningkatan denyut nadi seseorang dipengaruhi oleh latihan fisik (Sandi, 2016). Banyak macam latihan fisik yang dapat dilakukan seperti contohnya latihan Interval pendek. Interval pendek dapat meningkatkan daya tahan aerobik seseorang (Ulum, 2014). Latihan Interval juga dapat dilakukan untuk meningkatkan kebugaran jasmani, karena ada pengaruh Interval training terhadap peningkatan kebugaran jasmani (Prastyo, 2015). Untuk meningkatkan kelincahan dapat dilakukan latihan tabata, karena latihan meningkatan kelincahan secara signifikan (Romdani \& Agus Prianto, 2018). Latihan Resistance dapat dilakukan untuk meningkatkan kekuatan otot tungkai dan 
kelincahan, karena pada latihan Resistance akan meningkatan daya ledak otot tungkai dan kelincahan (Mardhika, 2017). Sedangkan untuk meningkatkan unsur daya ledak otot tungkai melakukan latihan Rope Jump. Latihan tersebut dapat dijadikan salah satu bentuk latihan untuk meningkatkan kekuatan otot tungkai yaitu dengan metode Interval Training (Aisyah, 2015).

\section{Simpulan}

Berdasarkan hasil analisis data dari lima komponen tes kondisi fisik peserta ekstrakurikuler futsal putri SMA Negeri 2 Batu, unsur daya tahan kardiovaskular menunjukkan kategori "Kurang", unsur kelincahan menunjukkan kategori "Rata-rata", unsur kecepatan kategori "Kurang", unsur daya ledak otot tungkai menunjukkan kategori "Di bawah rata-rata", dan unsur kelentukan menunjukkan kategori "Rata-rata". Secara keseluruhan kondisi fisik peserta ekstrakurikuler futsal putri SMA Negeri 2 Batu dalam kategori "Cukup". Dari lima unsur kondisi fisik yang sudah diteliti terdapat 2 unsur yang berada pada kategori rata-rata yaitu kelincahan dan kelentukan, sedangkan unsur daya tahan, kecepatan dan daya ledak berada pada kategori di bawah rata-rata dan kurang. Melihat hasil penelitian tersebut dapat dikatakan bahwa tingkat kondisi fisik peserta ekstrakurikuler futsal putri SMA Negeri 2 Batu masih rendah. Dalam hal ini peneliti menyimpulkan beberapa penyebab rendahnya kondisi fisik peserta ekstrakurikuler diantaranya frekuensi latihan yang belum sesuai dengan olahraga prestasi dan latihan fisik yang jarang diberikan oleh pelatih ekstrakurikuler futsal putri SMA Negeri 2 Batu.

\section{Daftar Rujukan}

Aisyah, K. D. (2015). Pengaruh Latihan Rope Jump Dengan Metode Interval Training Terhadap Kekuatan Otot Tungkai. Jurnal Kesehatan Olahraga, 3(1), 79-86. Retrieved from https://jurnalmahasiswa.unesa.ac.id/index.php/jurnal-kesehatanolahraga/article/view/11171/7666

Dewangga, W. (2014). Pengaruh Peningkatan Intensitas Latihan Futsal Terhadap Vo 2 Max Naskah Publikasi. Retrieved from http://eprints.ums.ac.id/32839/12/NASKAH PUBLIKASI.pdf

Gunawan, Y. R., Suherman, A., \& Sudirjo, E. (2016). Hubungan Kecepatan Dan Kelincahan Terhadap Kemampuan Dribbling Bola Futsal Pada Atlet O2Sn Kecamatan Sumedang Utara. 1(1), 1-12. Retrieved from http://ejournal.upi.edu/index.php/SpoRTIVE/article/view/3413

Hadi, F. S., Haryanto, E., \& Amiq, F. (2016). Pengaruh Latihan Ladder Drills Terhadap Peningkatan Kelincahan Siswa U-17 Di Persatuan. Jurnal Pendidikan Jasmani, 26(1), 213-228. Retrieved from http://journal.um.ac.id/index.php/pendidikan-jasmani/article/view/7748

Johan Cahyo B. F., Musyafari, S. R. W. (2012). Pengaruh Latihan Lompat Kijang Terhadap Kecepatan Lari. JSSF (Journal of Sport Science and Fitness), 1(1). Retrieved from https://journal.unnes.ac.id/sju/index.php/jssf/article/view/207

Lhaksana, J. (2011). Taktik dan Strategi Futsal Modern. Jakarta: Be Champion.

Mardhika, R. (2017). Pengaruh Latihan Resistance dan pyometric terhadap kekuatan otot tungkai dan kelincahan pada pemain futsal. Wahana, 68(1), 5-12. Retrieved from http://jurnal.unipasby.ac.id/index.php/whn/article/view/626/494

Palar, C. M., Wongkar, D., \& Ticoalu, S. H. R. (2015). Manfaat Latihan Olahraga Aerobik Terhadap Kebugaran Fisik Manusia. Jurnal E-Biomedik, 3(1). https://doi.org/10.35790/ebm.3.1.2015.7127

Prastyo, B. W. (2015). Pengaruh Pemberian Latihan Interval Training Terhadap Peningkatan Kebugaran Jasmani Wasit Komunitas Futsal Malang ( $\mathrm{Kfm}$ ). 5(1), 1-6. Retrieved from http://journal2.um.ac.id/index.php/sport-science/article/view/5241/2804

Purnomo, R. H. (2018). Hubungan Kecepatan, Kelincahan dan Kelentukan dengan Kemampuan Menggiring Bola Dalam Permainan Futsal pada siswa Ekstrakulikuler di SMP Negeri 3 Kota Kediri. Universitas $\begin{array}{llll}\text { Nusantara } & \text { Pgri } & \text { Kediri. } & \text { Retrieved }\end{array}$ http://simki.unpkediri.ac.id/mahasiswa/file_artikel/2018/13.1.01.09.0295.pdf 
Putra, S. (2014). Kontribusi Daya Ledak Otot Tungkai Terhadap Kemampaun Shooting Futsal Pemain SMA 6 Kota Bengkulu. 4(2), 1-6. Retrieved from http://repository.unib.ac.id/9075/

Rahayu, T. (2017). Penataran Pelatih Olahraga Tingkat Muda. Jakarta: Koni Pusat.

Romdani, S., \& Agus Prianto, D. (2018). Pengaruh Latihan Latihan Tabata Circuit Training Terhadap Peningkatan Kelincahan Pada Pemain Futsal. Jurnal Prestasi Olahraga, 1(4), 1-5. Retrieved from https://jurnalmahasiswa.unesa.ac.id/index.php/jurnal-prestasiolahraga/article/view/25930/23762

Sandi, I. (2016). Pengaruh Latihan Fisik Terhadap Frekuensi Denyut Nadi. Sport and Fitness Journal, 4(2), 1-6. Retrieved from https://simdos.unud.ac.id/uploads/file_penelitian_1_dir/63e5b8c7cbf295ecde33ac8d7b1ff962.pdf

Satria, M. H. (2019). Pengaruh Latihan Circuit Training Terhadap Peningkatan Daya Tahan Aerobik Pemain Sepakbola Universitas Bina Darma. Jurnal Ilmiah Bina Edukasi, 11(01), 36-48. https://doi.org/10.33557/jedukasi.v11i01.204

Sumantri, Y., Supriatna, E., \& Syukri, M. (2013). Pengaruh Permainan Futsal Terhadap Kemampuan Vo2 Max Siswa Di Smp. Jurnal Pendidikan Dan Pembelajaran, 2(6). Retrieved from http://jurnal.untan.ac.id/index.php/jpdpb/article/view/2156/pdf

Ulum, M. F. (2014). Pengaruh latihan interval pendek terhadap daya tahan anerobik pada pemain hoki SMA Negeri 16 Surabaya. Jurnal Kesehatan Olahraga, 2(1), 1-10. Retrieved from https://jurnalmahasiswa.unesa.ac.id/index.php/jurnal-kesehatan-olahraga/article/view/6329

Wiarto, G. (2013). Fisiologi dan Olahraga. Yogyakarta: Graha Ilmu. 